\title{
Erratum to: Biodegradation of a commercial mixture of the herbicides atrazine and S-metolachlor in a multi-channel packed biofilm reactor
}

\author{
Alberto Cabrera-Orozco ${ }^{1}$ - Silvia Patricia Galíndez-Nájera ${ }^{2}$ - Nora Ruiz-Ordaz ${ }^{1}$. \\ Juvencio Galíndez-Mayer ${ }^{1}$ • Fernando Martínez-Jerónimo ${ }^{1}$
}

Published online: 1 April 2016

(C) Springer-Verlag Berlin Heidelberg 2016

Erratum to: Environ Sci Pollut Res

DOI 10.1007/s11356-016-6204-5

The original publication of this paper unfortunately contains a mistake.

In the names of the authors, the fifth author should be Fernando Martínez-Jerónimo, instead of Francisco Fernando Martínez-Jerónimo.

The online version of the original article can be found at http://dx.doi.org/ 10.1007/s11356-016-6204-5.

Nora Ruiz-Ordaz

nruizo@encb.ipn.mx; noraruizordaz@yahoo.com.mx

$\triangle$ Juvencio Galíndez-Mayer

juvenciogm@yahoo.com; cmayer@encb.ipn.mx

1 Laboratorio de Bioingeniería, Escuela Nacional de Ciencias Biológicas, Instituto Politécnico Nacional, Carpio y Plan de Ayala, Col. Santo Tomás, CP 11340, ENCB-IPN, México, D.F, Mexico

2 School of Chemical Engineering and Analytical Sciences, The University of Manchester, Oxford Rd, Manchester M60 1QD, UK 